\title{
A Deleuzean Look on Tony Gatlif's Accented Cinema
}

\author{
Ahmet Oktan* \\ Almila Nur Berilğen**
}

\begin{abstract}
This study aims to discuss Tony Gatlif's "accented cinema", which deals with the lives of minorities and nomads and the reflexivity brought by these lives in many of his films, in terms of philosophical expansions. The unique style which the director builds by using cinema's means about being a Gypsy or from an ethnic minority while opening the majority to questioning transforms the film-watching experience into a specific intellectual adventure. In Gatlif's approach, which includes elements that coincide with Hamid Naficy's definition of "accented cinema", nomadism emerges as a minor element and, nomadic Gypsy communities, inside all the inhabitants of the world, display a minor existence. This philosophical reflexivity in Gatlif's films, which is similar to Franz Kafka in terms of masterfully presenting words of a minor community, is examined by focusing on, Latcho Drom (1992), Gadjo Dilo (1997), Exils (2004), Transylvania (2006) and Korkoro (2009) films. Questions like revealing reflexivities in terms of the director's accented images and what these elements mean on account of difference and minor cinema debates form the film analyses' basic questioning fields and the obtained findings are discussed by taking reference to Gilles Deleuze and Felix Guattari's concepts who see cinema as a philosophical perception and thinking activity. In this context, Deleuze and Guattari's ontology of difference and minor cinema approach is the intellectual background of this study to be made on Gatlif cinema.
\end{abstract}

Keywords: "Minor cinema", "accented cinema", difference, nomadism, deterritorialization.

\footnotetext{
${ }^{\star}$ Assoc. Prof. Dr., Ondokuz Mayis University, Faculty of Communication, Samsun, Turkey.

E-mail : ahmet.oktan@omu.edu.tr

ORCID : 0000-0002-2618-2127

DOI: $10.31122 /$ sinefilozofi.889331

** Ondokuz Mayıs University, Institute of Social Sciences, Samsun, Turkey.

E-mail : almilanur.berilgen@gmail.com

ORCID : 0000-0002-3691-7270

DOI: $10.31122 /$ sinefilozofi.889331

Oktan, A., Berilğen, N.A., (2021). A Deleuzean Look on Tony Gatlif's Accented Cinema. Sinefilozofi Dergisi, Özel

Say1 (3) . 312-329. https//doi.org//10.31122/sinefilozofi.889331
} 
-Araştırma Makalesi-

\title{
Tony Gatlif'in Aksanlı Sinemasına Deleuzyen Bir Bakış
}

\author{
Ahmet Oktan* \\ Almila Nur Berilğgen**
}

\section{Özet}

Bu çalışma, azınlıkların ve göçebelerin yaşamların ve bu yaşamların getirdiği düşünümselliği pek çok filminde konu edinen Tony Gatlif in "aksanlı sinema"sını felsefi açılımlar bağlamında tartı̧̧mayı amaçlamaktadır. Yönetmenin, filmlerinde, Çingene ya da etnik bir azınlıktan olmak üzerine sinemanın araçlarım kullanarak inşa ettiŏi özgün üslup, majör olanı sorgulamaya açarken, film izleme deneyimini kendine özgü bir düşünsel serüvene dönüştürmektedir. Hamid Naficy'nin "aksanl sinema" tanımlamasıyla örtüşen unsurlar da barındıran bu yaklaşım içerisinde göçebelik; minör bir öğe olarak ortaya çıkmakta ve tüm dünyanın yerleşik halklarının içerisinde göçebe Çingene toplulukları da minör bir varoluş sergilemektedirler. Minör bir topluluğa ait sözün ustalıklı bir biçimde sunulması açısından Kafka ile benzerlik gösteren Gatlif'in filmlerinde yer bulan bu felsefi düşünümsellik, yönetmenin Latcho Drom, Gadjo Dilo, Exils, Korkoro ve Transylvania filmlerini merkeze alarak incelenmektedir. Yönetmenin aksanlı imajlan bağlamında açığa çıkan düşünümsellikler ve bu unsurların fark ve minör sinema tartışması bakımından ne ifade ettiği gibi sorular, film analizlerinin temel sorgulama alanların oluşturmaktadır. Elde edilen bulgular, sinemayı felsefi bir duyuş ve düşünüş etkinliği olarak gören Deleuze ve Guattari'nin kavramları referans alınarak tartışılmaktadır. Bu kapsamda Gilles Deleuze ve Felix Guattari'nin fark ontolojisi ve minor sinema yaklaşımlar, Gatlif sinemasına yönelik yapılacak incelemenin düşünsel arka planın oluşturmaktadır.

Anahtar Kelimeler: "Minör sinema", "aksanlı sinema", fark, göçebelik, yersizyurtsuzlaşma.

\footnotetext{
${ }^{\star}$ Doç.Dr, Ondokuz Mayıs Üniversitesi, İletişim Fakültesi, Samsun, Türkiye.

E-mail : ahmet.oktan@omu.edu.tr

ORCID : 0000-0002-2618-2127

DOI:10.31122/sinefilozofi.889331

** Ondokuz Mayıs Üniversitesi, Sosyal Bilimler Enstitüsü, Samsun, Türkiye.

E-mail : almilanur.berilgen@gmail.com

ORCID : 0000-0002-3691-7270

DOI: $10.31122 /$ sinefilozofi.889331

Oktan, A., Berilğen, N.A., (2021). A Deleuzean Look on Tony Gatlif's Accented Cinema. Sinefilozofi Dergisi, Özel Say1 (3) . 312-329. https// doi.org//10.31122/sinefilozofi.889331
} 


\section{Introduction}

Commemorating cinema together with philosophy, studies approaching cinema as a kind of philosophical act have recently increased, but there has been a close relationship between the art of cinema and philosophical thought for a long time. Efforts to direct the audience to intellectual inquiries through cinematic images, and the transformation of images into means of thought creation have been the concerns of many leading directors in the history of cinema. Thinking through cinematic images, intellectual questioning carried out using cinematic language instruments, while expanding the meaning-making capacity of cinematic codes unlimitedly on the one hand; on the other hand, the philosophical concepts and intellectual expansions are inquired through images; and interactions, parallelisms, and commonalities are built between these two fields advancing in their own lines in terms of making sense of existence.

French director of Algerian descent, Tony Gatlif's works, which handle Gypsies' or nomads' lives that try to survive their existence inside major societies and cultures in various intellectual inquiries, are the distinct examples of philosophizing by way of cinematic images. In many of his films, Gatlif, issues minorities, and nomads' lives and the reflexivity these lives bring. Opens the major one to question with his unique style, which he built using cinematic means in the context of being Gypsy or from an ethnic minority. In Gatlif's approach, which includes elements that coincide with Hamid Naficy's definition of "accented cinema", nomadism emerges as a minor element and, nomadic Gypsy communities, inside all the inhabitants of the world, display a minor existence. In this respect, Gatlif's approach largely overlaps with the "minor cinema" conceptualization which Gilles Deleuze emphasizes as "modern political cinema" in the book Cinema 2: The Time Image (1997), derives from the "minor literature" approach that Deleuze and Felix Guattari define in the context of Franz Kafka's works. This study, which aims to question what kind of intellectual expansions are ensured in terms of a possibility of a minor becoming through cinematic images of Tony Gatlif over a sample chosen from the films of the director that concentrate on nomadism; focuses on this inquiry both in terms of the signs the director present through the images, and, usage of cinema's opportunities while generating these images.

In the study, at first, the accented features of Gatlif cinema, which is evident in terms of nomadism, will be examined briefly, related with the director's own biography, and tried to understand Gatlif's approach regarding nomadism and minor becoming. In the upcoming parts of the study, the philosophical reflexivity found in Gatlif's films that show similarities with Kafka in terms of presenting the words of a minor community masterfully is examined by focusing on Gatlif's Latcho Drom (1992), Gadjo Dilo (1997), Exils (2004), Transylvania (2006) and Korkoro (2009) films. It is discussed how nomadism and the process of nomadization make sense by focusing on both the elements that define the characters and the journeys they make in the space. In this discussion about the transformation processes of the characters, their relations with each other, places, cultural elements, and nature are also included. It is researched how language, music, dance, places that make up the different aspects of the phenomenon of nomadism are interpreted, and what choices are made regarding the language of cinema. All these elements are tried to be interpreted as instruments of Gatlif's philosophical discussion on nomadism.

In this context, Hamid Naficy's conceptualization of "accented cinema" and Gilles Deleuze and Felix Guattari's ontology of difference and minor cinema approaches constitute the intellectual background of the analysis to be made on Gatlif's cinema. Reflexivities revealed in the context of the director's accented images and the questions of what these elements mean in terms of difference and minor cinema discussion constitute the main areas of inquiry in film 
analysis and the findings are discussed by taking reference to Deleuze and Guattari's concepts who see cinema as a philosophical perception and thinking activity.

\section{Accented Voice of Tony Gatlif Cinema}

Tony Gatlif, whose real name is Michel Boualem Dahmani, was born in Algeria in 1948 to an Andalusian mother and an Algerian father. Gatlif, who grew up in a gypsy community near Casbah, migrates during Algeria's war of independence and settles in France. Gatlif, who is a musician, writer, poet, and director that multi-cultural, multi-identity, too much onthe-move to not to be placed under singular/constant identities, continues in a Gypsy and nomadic culture, just like his characters.

As Altun points out, Gatlif, with the gypsyism he adopted in ethnic and culture, turns his camera to the subalterns, the quieted, the oppressed, the angry, and most of all, the gypsies (Altun, 2016, 203). In a sense, the director voices his own story through the nomads/angers that he places at the center of his narratives: "I go spontaneously towards people like me" (Vanderschelden, 2014, p. 111). Gatlif, often, does not purport to speak out for and to represent the nomads or the angry who experience the traumas caused by post-colonial displacement and a kind of ethnic and cultural sticking in between in the diaspora; break away from the context they belong to due to the economic, political or ethnic strains of the major's hegemony, or define nomadism as a vital strategy. He expresses this approach in an article about Indignados film as "I've always been attached to people who rise up. I share the beliefs of all these people who are struggling, I am with them... I am not one of their representatives, I am an outrage from within them. And no one is their representative" (Gatlif, 2012).

Just as Gatlif himself is a nomad, in his films, the phenomenon of nomadism constitutes the main theme of the narratives. In an interview given in 2006, he describes his cinema in these words: "What I like are feelings, being on the road, discoveries... To me, cinema is taking people on a journey, but to a disordered one" (Çakan, 2009). In different films, Gatlif focuses on different types and different phases of migration. As in the example of Djam, although the process that causes migration is handled in a few films, Gatlif mostly focuses on the phenomenon of migration as a process. Many of his films, such as Gadjo Dilo, Latcho Drom, Transylvania, Mondo, Korkoro, Exils, begin when the main characters are on the brink of a migration or a journey, or they are inside the process of migration/journey and the characters are often in a quest. In films such as Wengo (2000), Geronimo (2014), Swing (2001), the narratives are based on characters who experience the post-migration process, but although there is a kind of spatial settlement in these films, the cultural and mental migration process has not been completed.
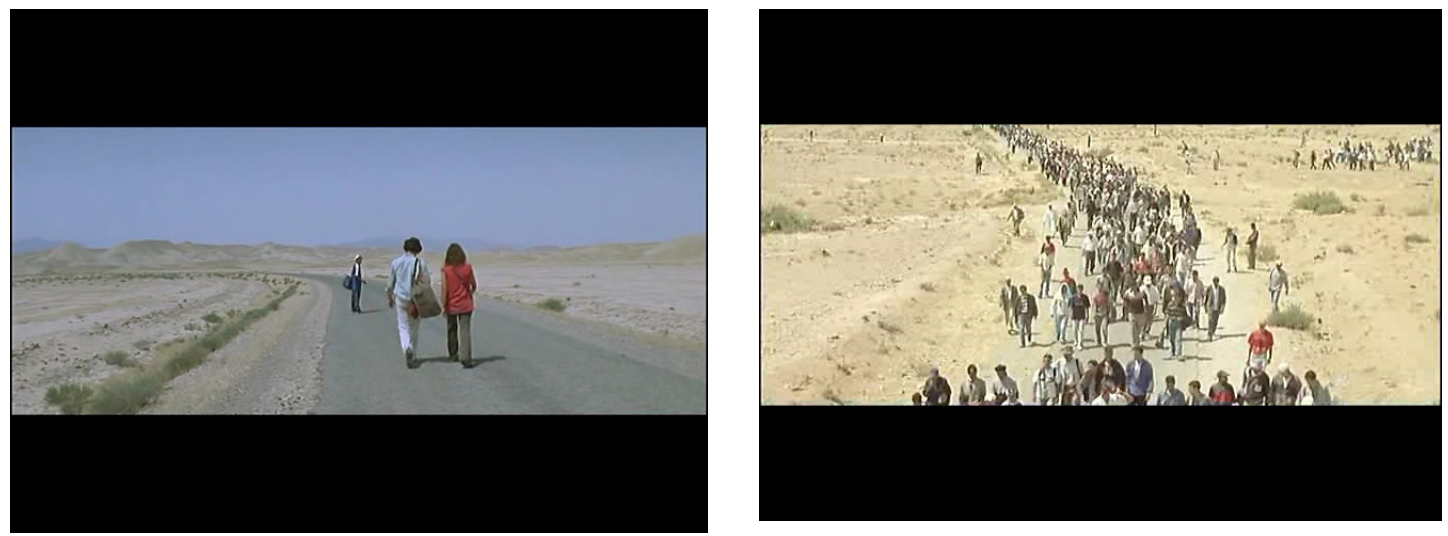

Images 1: Migration and journeys are important visual elements in Gatlif cinema: Scenes from Exils. 
These films have the characteristics of Accented Cinema with their migration-related features. In his book titled An Accented Cinema, Hamid Naficy states that Gatlif discovered his own "hybrid voice" after assuming his Gypsy identity (Naficy, 2001, p. 98) and presents his films as examples of the definition of accented cinema. Writers such as Sylvie Blum- Reid (2008), Andrew McGregor (2008), Isabelle Vanderschelden (2014) also discuss Gatlif cinema within accented cinema in terms of nomadism, deterritorialization, cultural metissage, or hybridism. Naficy divides the accented filmmakers into three main groups; exiled, diasporic, and post-colonial/ethnic identified filmmakers. Naficy classifies exile as an individual; diasporic as a collective experience. In the films of ethnically identified filmmakers having a dual identity or hyphenated identity, comprises the main area of inquiry. According to Naficy, this triple definition, in which accented filmmakers are classified, is inseparable from each other by precise lines. Naficy states that the point of originality may be evident in the way directors perceive and experience displacement (Naficy, 2001, pp. 11-17). Though Gatlif's place in this triple distinction of Naficy, who brought to classify the accented filmmakers, cannot be sharply drawn; it would be accurate to say the director creates works that consist of features of these three classifications.

The definition of Gatlif's cinema within such a category and the intercultural features it carries in terms of its accented features is doubtlessly a discussion worth dwelling on. However, depending on the main purpose of this study, how the director makes sense of the phenomenon of nomadism and Gypsyization and what kind of philosophical expansions this approach provides emerges as a significant question that needs to be discussed.

\section{Nomadism as an Immanent Difference}

In Tony Gatlif's films, migration and Gypsydom are generally defined in two axes. The first of these is the cultural fusion and hybridity rooted in migration, journey, and being on the road. The director emphasizes the significance of Gypsy communities as culture-bearers or as the agents of cultural hybridity with this approach. The multicolored, multi-voiced, and enthusiastic atmosphere reflected in the films is mainly the result of nomadism. The main direction to be focused on the director's approach on migration is the director's discussions on the meanings of nomadism. In these films, migration is perceived as a given phenomenon. Except for few examples, it is not emphasized on the cause for migration, the traumas it leads, etc, and nomadism is not negatively processed. Migration is reflected in the films, not as a transition, a journey with a beginning and an end, but as a search for uncertainty, that is, settling into uncertainty. Most of the characters in these films are wanderers. Sometimes they set out for a certain destination, but over time, they settle in migration, become nomads. For example, in Gadjo Dilo, Stephane's father is a wanderer, he himself also wanders with his memory of his father. In Transylvania, Tchangalo is a wanderer dealing in gold and silver, sleeping in his car. Zingarina also participates in this life. In Korkoro, the family in the center of the story is already a wandering gypsy family. Claude who is actually settled follows them because he is orphaned and at the end of the film, he also becomes a nomad. In Djam, Kagurgos and his family leave their homeland due to economic problems and become nomads. In Exils, Naima and Zano make such a journey on the route from France to Algeria. Similar stories also exist in films such as Mondo, Latcho Drom, etc.
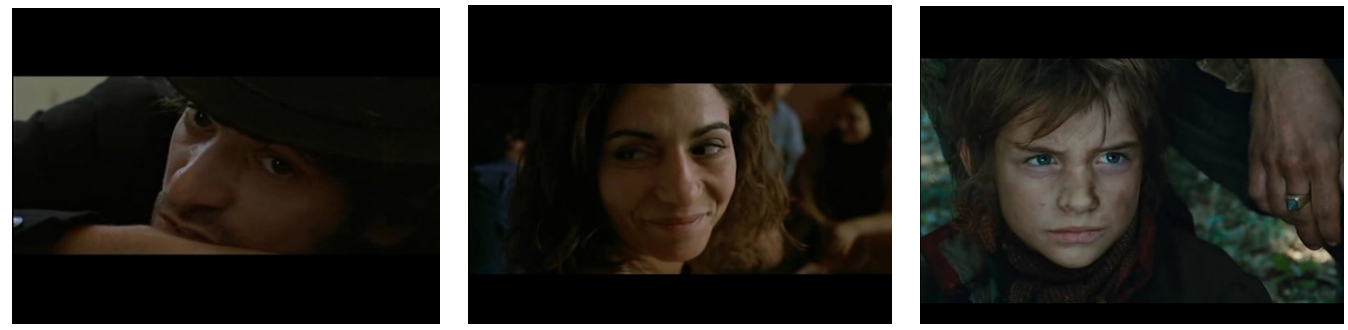

Image 2: Some of Gatlif's nomadic characters: Scenes from Exils and Korkoro. 
These characters who go on a journey as a part of a certain origin, a culture, a unity; are in search of a defined, certain bond of belonging, related with their own pasts that they can build their subjectivities on. It could be a place, a person, a melody, etc., that enables them to complete the deficiency in their being, make them whole, and construct their meaningful self. It's a singer carrying the memory of a lost father in Gadjo Dilo, again the memories of lost parents and a country to be exiled in Exils, an ex-lover in Transylvania, a family to be belonged to in Korkoro. However, the journeys of the characters in space and time throughout the film are experienced as a process that gradually distances them from the person they are at the beginning, alienates them from their own past, and detaches them from the major structures that establish their own identity. Journeys gradually turn into a process in which the characters' languages, clothes, bodies, and thoughts change completely. Each time, it results in completely abandoning the purpose set out or the spiritual position that is sought to be achieved and adopting a nomadic subjectivity (becoming a Gypsy in films).

At this point, the following questions become important: How can it be interpreted that the director making his characters destined to nomadism, in a sense, by purging from all belonging bonds, ethnical, spatial, cultural, etc.? What do these free spirits, whose belonging is to the roads, journeys and therefore do not fit into any of the presented classifications, tell to the audience with their new forms of existence? While thinking on the possible answers to these questions, it should be taken into account that this choice of the director is presented in an affirmative content and that both the cultural differences and the differentiation of the characters from their own essences are shown in a positive meaning in his films. In this context, Gatlif's approach corresponds to the philosophy of difference and nomadic subjectivity that can also associate with the minor cinema approach of Gilles Deleuze, one of the important thinkers of contemporary philosophy, and Felix Guattari whom he worked together on many works.

\section{Positive Perception of Difference and Nomadic Subjectivity}

Deleuze and Guattari, who placed the discussion of difference and nomadism on a significant situation in their philosophical approaches, argue that the tradition of western philosophy, rooted in Ancient Greece, negates difference and limits idea creation through with its features such as being based on identicalness, unity, dualist contrasts and producing hierarchies. According to Deleuze and Guattari (Deleuze \& Guattari, 2005, p. 18; Deleuze and Parnet, 2007: 13), the philosophy tradition founded on "tree-shaped way of thinking" and the search for essence or reality, tends to define everything on the axis of transcendentalized basic principles, and this confines thought within certain limits. Just like having a starting point of a tree (root) and forming the trunk, branches, etc. through deriving from this root, in other words, defining points of destination, the tree-shaped way of thinking is based on a certain basis or origin, and all the new connections exist in reference to the root. Concepts territorialized on a certain root or essence, fix the meaning and show a tendency to transform the difference via representations into identities. Structures based on power and mind that come into existence within this system of thought, approach negatively to the ideas and tendencies that go further from the center, and for this reason, change and pluralization are hindered.

However, for Deleuze, "concept creation" consists of the essence of the philosophical act. "Philosophy is the art of forming, inventing, and fabricating concepts." (Deleuze \& Guattari, 1994, p. 2). From this idea, Deleuze and Guattari (Deleuze \& Guattari, 1994; Deleuze, 1994; Deleuze, 2004), put the rhizomatic thinking based philosophy of becoming which is built on the difference being perceived with an affirmative content instead of the idea or subject-centered understanding of truth and major orientations peculiar to western thought that confines thought and life within certain limits.

Deleuze, just like the word tree, also takes the rhizom from the field of Botanics, and contrary to the tree; just as the rhizome not having a certain structure, not having a certain start or finish point, advancing without forming upper connections and by divaricating; rhizomatic 
thinking is not built on the essence and has got no certain route. "In contrast to centered (even polycentric) systems with hierarchical modes of communication and preestablished paths, the rhizome is a centered, nonhierarchical, nonsignifying system without a general and an organizing memory or central automaton, defined solely by a circulation of states" (Deleuze \& Guattari, 2005, p. 21).

The rhizomatic operation which is based on the randomness of the connections, through deterritorialization ${ }^{1}$ and escape points ${ }^{2}$, etc.; takes place as a form of direction to heterogeneity and plurality on the axis of difference. Power-based thinking forms and major structures producing oppression and uniformity, are uprooted, stuttered, and destabilized by being subjected to the deterritorialization process. As the major structures and ways of thinking are eroded, ideas and tendencies that move away from the center of the homogeneities are affirmed. Thus, these tendencies, which open to multiplicity, coincidence, and chaos by leaking through the cracks at the boundaries of the major structures and following bifurcated, proliferating paths and lines of flight; enable "becoming" which is an original perception of the being.

Becoming, in Deleuze's philosophy, corresponds to the state of being, thought, or meaning in an endless transformation. This idea does not base the being on a certain base, essence, or origin. As Akyol Oktan emphasized (2019, p. 307), it corresponds to a state in which thought and being completely getting nomadic, opening to otherness, directing to become more than it is, and liberating from all molar structures by based on molecularity. This idea, which perceives being as nomadism in a smooth flow and a constant state of transformation, also opposes the subject idea which is based on certain integrity and structure. "The biggest hindrance to becoming is subjectivity. Deleuze's opposition to the subject idea involves a general affirmation of becoming. What needs to be done is to think without models, axioms, and facts; to pave the way for thought" (Colebrook, 2013, p. 171).

The approaches of Deleuze and Guattari briefly summarized here, are essentially based on a positive understanding of difference as a minor approach to being. In this understanding, tendencies getting away from the center are affirmed as productive multiplicities, enabling the enrichment of life. Thought In this understanding, tendencies getting away from the center are affirmed as productive multiplicities, enabling the enrichment of life. Contrary to the majorative idea, in this approach, the difference is evaluated on an immanent plane, not as a particular tendency emerging against integrity. As in Deleuze and Guattari's words "The difference is not at all between the ephemeral and the durable, nor even between the regular and the irregular, but between two modes of individuation, two modes of temporality" (Deleuze \& Guattari, 2005, p. 262). This is the proliferation of being or thought by differentiation in its own axis and the endless expansion of the difference by constantly repeating. In this approach, which is corresponding to Nietzsche's "eternal recurrence" notion, difference and repetition are the means that lead the idea to becoming, nomadism and liberation.

When viewed within the framework of these discussions, it can be said that the theme of nomadism that dominates Tony Gatlif's films, especially the progression of the narratives in the form of the gradual alienation of the main characters from their own identities; corre-

\footnotetext{
${ }^{1}$ Deterritorialization, is an approach that pust the codes and meaning systems formed inside a transcendental structure and all artificial identities of the natural ascribed to it by the dominant culture into crisis and alienates the elements to its essence which refer to the major one. By assigning other meanings to these elements, the ideological functioning is being interrupted. (Akay, 2006, pp. 13-15).

${ }^{2}$ Deleuze and Guattari; talks about three different lines immanent to each other that form a life. These are "molar lines", "molecular lines" and "line of flight" (2005, pp. 197-198). The molar line is related with molar structures, like state-apparatus. Molecular line is a concept that belongs to the field of fragmentation, flexibility, becoming, molecular. The line of flight which in between molar and molecular is the cracks, opening little incisions at the borders of the molar structures and open the being to molecularity. In Deleuze and Guattari's words "line of flight is like a train in motion, it is because one jumps linearly on it, one can finally speak "literally" of anything at all, a blade of grass, a catastrophe or sensation, calmly accepting that which occurs when it is no longer possible for anything to stand for anything else" (2005, p. 198).
} 
sponds to the Deleuze and Guarrati's thoughts of difference as a war machine that leads the being to plurality. Characters' alienation from everything that defines them, their gradually abandon their fixed identities corresponds to a kind of process of deterritorialization. So much so that the characters, who advance into an ambiguous and unpredictable situation by breaking away from everything that defines them, from their clothing to their bodily auras, from the values they bear to the language, also move away from the idea of constructing themselves as subjects and settle in a molecular form of subjectivity.
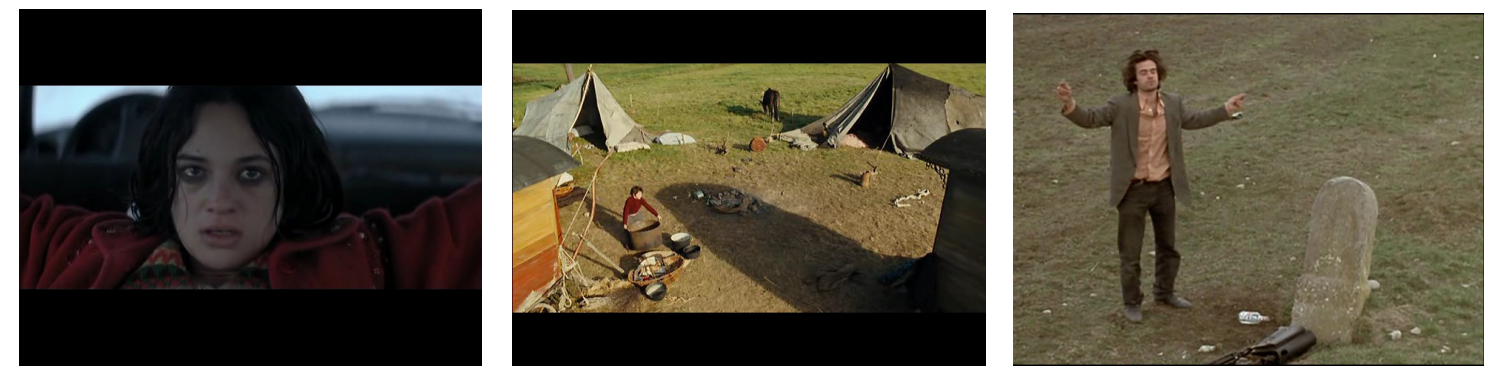

Image 3: The development of Gatlif's characters takes place in the form of a kind of deterritorialization: Scenes from Transylvania, Korkoro and Gadjo Dilo.

Deleuze and Guattari, describe such a kind of an irreversible deterritorialization as absolute deterritorialization. According to them (Deleuze and Guattari, 2005: 133), absolute deterritorialization is a liberation progress that opens up new ways which non-returning, bifurcated; and to indefinite probabilities. From this point of view, the transformation of the characters in Gatlif films into nomads can actually be interpreted as a liberation form that opens the characters to endless possibilities, renders the boundaries and obstacles meaningless, transforms them into purer souls in a symbolic sense. When considered in Deleuzian meaning, this situation of the characters fits the state described by the author as "becoming".

On the other hand, the aforementioned emancipation, as Çalcı has emphasized, can be considered not only as of the emancipation of the human being but also as the emancipation from the human (Çalc1, 2012, p. 22). It is possible to make sense, within this approach, that almost all of Gatlif's films, the characters' close relations with both domestic and wild animals, the characters' continuous, sometimes even naked, running in the forests, their integration with nature by lying on the ground, water and mud.
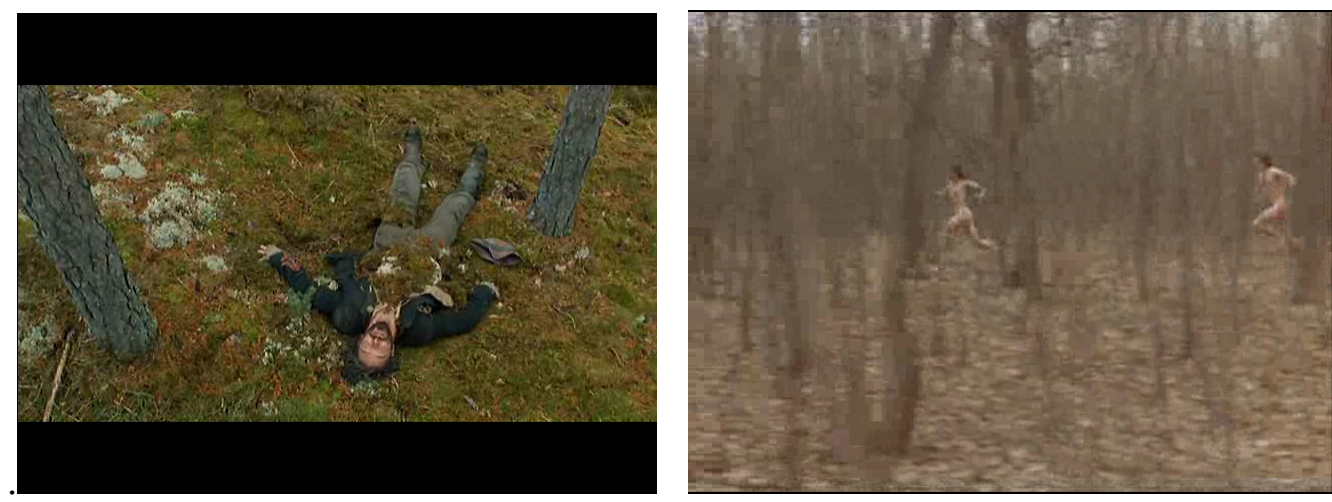

Image 4: Characters who integrate with nature step into being more than themselves: Scenes from Korkoro and Gadjo Dilo. 
Deleuze and Guattari put forward the philosophical understanding that they have established on the axis of the deterritorialization of the major, the positive perception of difference and nomadic subjectivity, which we have also identified in Gatlif cinema, as a minor and political perspective towards life and thought, and they open such an approach to a discussion in the context of literature and cinema. Deleuze and Guattari, classify the minor literature's features which are made in the minor language created inside a dominant language and by deterritorialization of this language in three main topics as; the deterritorialization of language, the politicization of the individual by connecting to the political, and the collective organization of discourse (Deleuze \& Guattari, 2020, p. 34). Deleuze, in his book, Cinema 2: The Time Image (1997), adapts his minor literature conceptualization in the field of cinema as well. The writer, though he does not exactly define how to adapt the minor idea to the cinema, emphasizes the elements of "minor cinema" by "modern political cinema" definition. Deleuze determines three basic features of this cinema style, made by directors such as Alain Resnais, Jean Rouch Jean-Marie Straub, Yılmaz Güney, Youssef Chahine, Glauber Rocha, Pierre Perrault, and Ousmane Sembene telling the stories of the characters, who living on the margins of society and trying to exist within the various othering policies of public powers. These features are the deterritorialization of existing identities or contributing to form a folk's identity, the blurring of the distinction between private and public spheres, and the proliferation and diversification of public identity (Deleuze, 1997, p. 218). These films that focus on characters aiming to build their own identities and constantly transform the identities of minor communities, seek the possibilities of minor existence in ghettos, camps, or on the edge of major communities.

Continuing a similar quest, Gatlif's cinema gains a minor cinema feature by trying to reveal new ways of thinking through nomadization or Gypsyization. Gatlif, re-interpreting the concepts of difference and otherness in his own style, realizes a minor becoming not by breaking majorative structures, but with a voice from the inside and by stuttering them. The director, perceiving nomadism as a liberation and creation of difference, reveals the opportunities of the minor cinema with both the meanings he produced through cinematic images and his preferences for the language of cinema.

\section{Language as a Border}

One of the striking aspects of Gatlif cinema in terms of nomadic becoming and minor cinema is the use of language. Director's films, as a return of nomadism, build up worlds that reflect multiculturalism and bring many languages together. Multilingualism is also a common feature of accented films as they are narratives of journeys across national borders and ethnic coexistences. However, in Gatlif films, most of the time, the language comes up as an element that hinders the communication between characters. Especially at the beginning of the stories, the words anticipated to make characters communicate, consist of sounds that do not have any correspondence among characters. The limitations caused by the language are tried to be eliminated with its deterritorialization and alternative communication possibilities. Languages that have completeness, grammar, a syntax in themselves; become hybridized and alienated from their own system and accent in these films. Singular words used independently from the linguistic rules that complete themselves; are most of the time equipped with meanings close to what they have, but, to a certain extent, are equipped with alienated meanings. Thus, a relationality that goes beyond the boundaries of language becomes possible by deconstructing the language or producing alternatives like music, signs, dance.

In most of the films examined, interactions that cannot be established within the closed structure of the language lead the characters to alternatives. For instance, in Gadjo Dilo, even though the protagonist Stephane, at first, tries to communicate with the Gypsies through language, they don't understand each other. In their first encounter, the Gypsy women use this miscommunication situation of speaking a different language to make fun of Stephane. Language appears as a hindrance, a limit in Stephane's first conversation with Izidor, as well. 
They begin to understand each other and establish human intimacy, gradually, only by trying ways beyond the limits of language. From this stage on, the faces of the characters begin to be displayed with closer plans, and the expressions on their faces turn into an important tool in the production of the meaning of the film. While that the characters begin to transcend the boundaries offered by the major structures to which they belong, allows the formation of various emotions and refined bonds, the director tends to produce affection-images with his cinematography preferences.

In most of the films, as the narrative progresses, words taken from more than one language are combined, produce an alternative, common language, and the boundaries caused by the language are removed. The deterritorialization of the language and new language practices produced inside a kind of intercultural eclectism, in a way, corresponds to a process of passing a transnational border. The erosion regarding the language inside Gatlif's deterritorialization machine's operation which nomadizes the characters takes place not only in the form of crossing beyond a cultural border but also becoming meaninglessness of a unity that establishes the identity of characters. In other words, the alternatives that are tried to be formed by groping to overcome the limitations of the language and make communication possible, are in fact like an inevitable prerequisite of the characters estranging from themselves and establish their new subjectivities in the axis of differentiation from themselves.

The deterritorialization of language, its meaning as a kind of transgression and with positive content, is a condition of going beyond the "subject", which is defined as a form of normality in the view of writers such as Friedrich Nietzsche, Gilles Deleuze, and Felix Guattari. Nietzsche, in Beyond Good and Evil (2007, p. 35), speaks about an irony related to breaking the grammar to overcome modern subject's reduction of the philosophical universe to the ideas in his mind, forming the being over its own laws, and the dominant perspective by transforming the law that the mind fictionalized in its own self to the reality of the nature. What Nietzsche meant by overcoming grammar is not merely a form of deterritorialization that describes the language. However, grammar in the linguistic sense constitutes an important dimension of this irony, since language has undertaken a founding function in the establishment of the idea of approaching existence with the perspective of law and order, which he basically is in a struggle with. Deleuze and Guattari also attribute a political value to language by establishing parallelism between the grammar of a language and social laws in A Thousand Plateaus. In this context, "making grammatically correct sentences is a prerequisite for any submission to social laws for the normal individual" (Deleuze \& Guattari, 2005, p. 101). Deleuze and Guattari, in their work, titled, Kafka: Toward a Minor Literature (2020), also establish a link between language and the relations of domination and control, and search for a minor becoming as a political attitude in the deterritorialization of the grammar and syntax of the major language.

Considered within the framework of these discussions, the images of language in Gatlif's films are the tools of the director to establish nomadism as a form of political resistance that opens existence to becoming.

\section{Music and Dance as a Rhizomatic Flow}

Music, which is the memory of Gypsy in Gatlif films, functions as a narrative element that transcends cultural boundaries, goes beyond the domain of the state apparatus and opens the door to multiplicity by bringing different cultures together in the same spaces. Music is perhaps the most important alternative used in these films to provide such an interaction, as language becomes an obstacle in establishing communication between characters who do not speak the same language. With its nature that transcends cultural boundaries, music allows establishing of bonds that words cannot, to make sense of each other's worlds for the characters, and to establish a dialogic relationship. For example, in Gadjo Dilo, the first obstacles caused by language between Izidor and Stephane begin to be overcome when Stephane makes Izidor listen to Nora Luca's song. In addition, in the scene in which Stephane wants to leave Izidor's 
house to continue his search, Izidor plays the melodies of his own culture with his violin and convinces Stephane to stay. Stephane's choice to stay and slowly established bonds, change the neighbors' attitude towards this stranger quickly.

Music of different cultures is brought together in a carnivalesque atmosphere by being cut off from their own contexts and often by overlapping melodies, sounds, and dances. In Transylvania, Gadjo Dilo, Exils, Latcho Drom, and Geronimo and in many films, it is observed that sometimes characters in the scene and sometimes the melodies of different cultures in the music band overlap, jointed to each other and complete each other. For example in Geronimo, the director, composes a piece of hybrid music by blending Spanish, French instruments/ melodies with a Turkish folk song performed by Aysun Gültekin and with this song, brings together the tension between two different gangs and Flamenco dance.
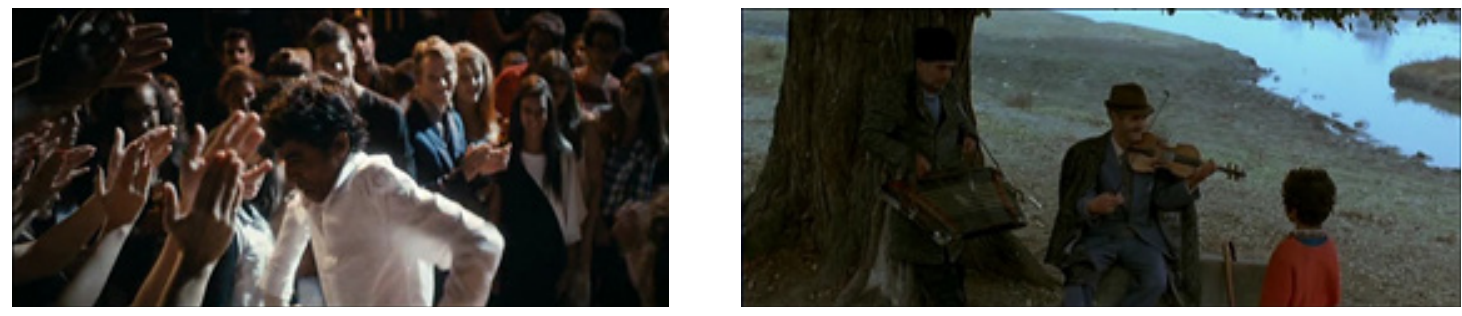

Image 5: Music and dance remind of the possibility of a non-linguistic relationality: Scenes from Geronimo and Latcho Drom.

The place of music and dance, which are the best representing elements of nomadic culture in Gatlif films, is almost equivalent to a protagonist. Music and dance in these films are tools that enable the others in the major structures to express the words of the minor and to say something for themselves. These sounds and melodies are deterritorialized by being detached from their context and become an element of alienation that disrupts the sensory-motor mechanism of the audience, an instrument that allows thought to sprout. In Transylvania, in the scene where Zingarina helps the old man, the anthem she sings while riding her bicycle, raising her hand as if on a walk ("Forward friends. Forward workers! Forward, comrades! Our red flag crosses borders! Our red flag crosses borders! Long live socialism and freedom!") stutters the narrative, produces a kind of reflexivity by alienating the viewer from the meta-order of the film. Within this preference of Gatlif, founding elements that are immanent to music like time, place, culture, and language all become invalid. Melodies and words that have no connection with the context it is in, derive suddenly from a dialogue related to other topics between the characters. Music and words become rhizomatic, turn into rhizomes.

Gatlif, who is also a good musician, conveys the main idea of many of his films with nondiegetic and aphorism-like words within the music generation. For example, the words heard in a high tone accompanied by music in the beginning scenes of Gadjo Dilo and Exils movies or the last scene of the movie Korkoro are manifestos. The words of the subordinates, outcasts, people looking for their own ways meet the sad and enthusiastic voice of Gatlif's melodies. The music that voices rebellion against the major, authority, oppression, and praises to minor opportunities, peace, life, and democracy; contributes highly to director's cinema, which he built on a small group, in having a political content. The lyrics reflecting the rebellion against the exclusion and violence against Gypsies in Gadjo Dilo with the words "God, why am I so dark?", in Exils, advise speaking, to inquire:

"We must talk about the ones fading away right away. Now is the time to talk about the ones that make mistakes. We must inquire who fade away. We must inquire the liars that act as if they are democrats. We must talk about the ones fading away right away. We must talk about the ones we lost right away. Now is the time to talk about wrongdoers. We must talk about freedom right away. We need to inquire the ones fading away. We must inquire the liars that act as if they are democrats" (Gatlif, 2004). 
To sum up, in Gatlif films, dominant communication models are interrupted by music and dance, and an alternative communication model is established. Thanks to these elements normative values are questioned and an opportunity to look from a different perspective is given to the viewer. From this point, Gatlif cinema, due to the political ingredient it holds in terms of using music and dance, gains a minor cinema feature.

\section{Fluid Spaces}

In Tony Gatlif's accented cinema, the characters' existential journeys towards their own past or inner worlds take place in fluid spaces. The areas where the director structures nomadism in his films are often intermediate spaces that transform quite quickly and do not belong to any context. These intermediate spaces, which Naficy emphasizes in the context of accented cinema, and which appear in Gatlif's films as borders, highways, train stations, abandoned vehicles, forested areas, or towns and villages that are not understood to which country or city they belong, are the liberation spaces that produce plurality and nomadism instead of majorative structures.

Space is the fundamental element that builds memory. However, Gatlif's spaces, who basically build his films on forgetting, are almost nomadic. There is no turning back to the same place again in most films. These places where the characters carry out their search in a purged way from their bonds, are almost memoryless like the characters and are the means of erosion of memory, the tendency towards becoming and multiplicity.
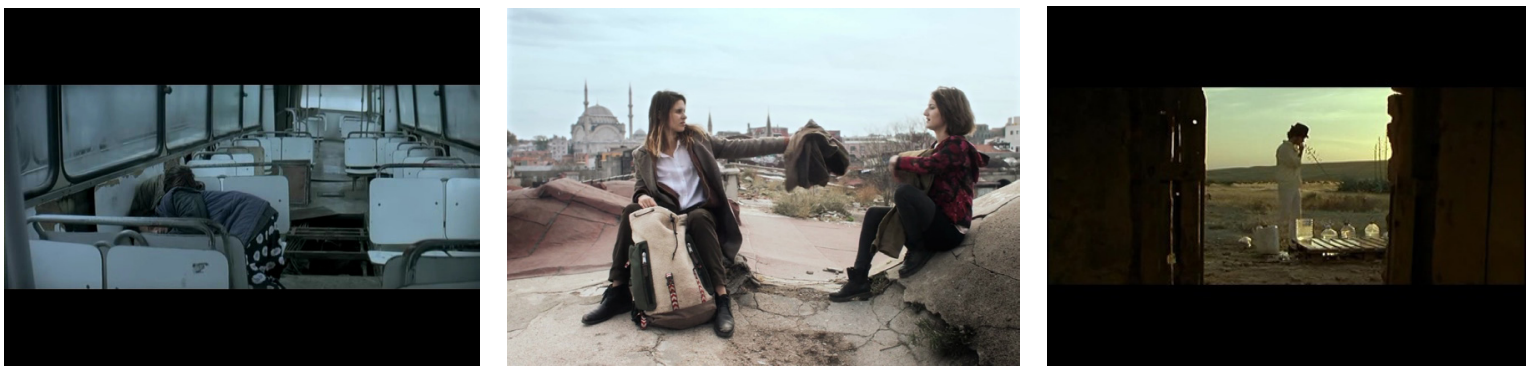

Image 6: Gatlif's spaces draw attention with their heterotopic features:

Scenes from Transylvania, Djam and Exils.

This aspect of Gatlif's spaces brings to mind Michel Foucault's conceptualization of heterotopia. In his article, titled OfOther Spaces: Utopias and Heterotopias (1997) Foucault, describes heterotopia as a kind of in-between space. Heterotopias are areas of intersection that overlap disparate time layers or incompatible spaces. For example, cemeteries that unite life and death, which are impossible to coexist, or museums that allow different time layers to accumulate on top of each other are examples of heterotopias. Moreover, Foucault talks about the kinds and different features of heterotopia. One of the most distinctive features of heterotopia in the author's approach is that it is a transitional space between a site or civilization that exemplifies an oppressive life, and a utopia that describes an ideal life but only exists in dreams. Foucault describes heterotopia as a liberating space from the oppressive, anthropocentric, and exclusionary structure of the site, which provides a distance from the site. Just as heterotopia is an in-between space that allows the establishment of utopian dreams that can be an alternative to the site, in Gatlifin's films, characters who go beyond their major identities are also in a kind of search in these spaces.

Foucault, in his article, emphasizes that one of the features of the heterotopia is, ephemerality (Foucault, 1997, p. 7). Stavrides also emphasizes that heterotopias "are as places of discontinuity, cracks in the moulding classifications of space and time, as irregular fragments of space and time come together in the processes that provide a place to emergent social relations" (Stavrides, 2016: 158). Places in Gatlif's films have similar characteristics in terms of both transforming continuously and establishment cinematographic presentation on the axis 
of speed. Because the stagnation of the space will bring the transformation of life into a permanent system and losing its liberating potential. In this aspect, heterotopia resembles Deleuze's "becoming nomadic" concept. Gatlif's heterotopias, in a way, are the spaces of flight that enable Deleuzean nomadic subjectivity. The characters, who have turn into nomads, move to ambiguities whose direction, target, and time are uncertain via the paths that open and bifurcate in heterotopic spaces.

\section{Carnivalesque and Dialogical Relations}

Characters in Gatlif cinema live in a carnivalesque atmosphere related to being multivoiced, multicolored, multi-cultured which is brought about by Gypsy culture and nomadism. Carnivalesque elements become plural, especially in parallel with the characters' alienation from their own past and becoming nomadic. The narrative, in which music, clothes, and dances intertwine, becomes polyphonic, complicated, and sometimes even schizophrenic, gradually gains the appearance of a carnival. While the life strategies of the characters based on their own reality and logical integrity lose their functionality, the states of consciousness give way to confusion, the state of the subject to hybridity, the bonds of belonging to nomadism, in short order to carnivalesque.

Michael Bakhtin, one of the important critics of literature, (2001, p. 238) defines carnivals as liberating spaces. According to Bakhtin, while the nobles, the rich, the poor, people from different social classes come together in the carnival, the distances between people are suspended. While leaving their own identities temporarily in carnivals, people who are separated in their usual lives by impervious hierarchical obstacles, interact with each other in carnivals. Instead of hierarchies and inequalities, more relational, in Bakhtin's words, dialogic relations are established. This form of relationship corresponds to a conciliatory and democratic interaction that emphasizes interaction and equivalence with the other.
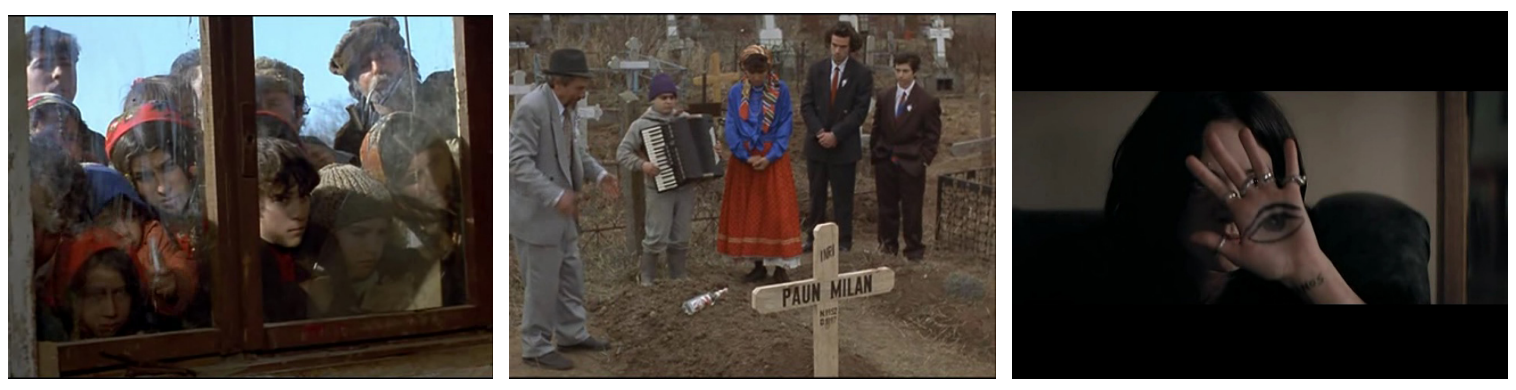

Image 7: In most of Gatlif's films, order gives way to carnivalesque: Scenes from Gadjo Dilo and Transylvania.

In Gatlif films, non-human beings also play an important role in the establishment of such an interaction and the formation of the carnivalesque structure. It is not only languages, places, characters, or music that are taken out of context in these films. Animals go through a similar fate. Animals, which are constantly included in the narrative with their voices and images, and the bonds they form with people in films, on the one hand, reflect an attitude that affirms difference and prioritizes a dialogic relation between species, and sometimes they are included in the film as a surprise element that brings randomness and uncertainty to the agenda. For example, a bear suddenly appears in an unexpected place in a town in Transylvania.

In terms of perceiving being on an axis of posthuman plurality, the interactions of characters with nature are also noticeable. Such that, in most of these films, people are seen as integration with the forest, soil, rotten leaves, rain, ponds, animals, and such elements. In these films, there are scenes in which the camera pans followed the characters running, sometimes naked, among the trees. This preference of visualization, which increases the sense of speed, and emphasizes freedom, is used to describe the liberation brought about by the nomadism that Gatlif generated through his characters and the interaction with nature. Such elements also voice an alternative to anthropocentric comprehension due to their dialogical relations with nature. 


\section{Visualization Strategies and Cinematic Searches}

Minor cinema composed by Tony Gatlif with themes such as deterritorialization of the major and stabilities through stuttering; nomadism approach built on difference and repetition axis in terms of Deleuzean difference ontology; placing carnivalesque instead of oppression, order, and hierarchy; pursuits of characters in heterotopic spaces are valid in terms of chosen visualization concepts and cinematic language. In this framework, it is seen that the director presents a style of cinema that takes place in the intersection of reality and fiction that oscillates between fiction and reality. The director builds this style of cinema by making both documentary and fictional films, and in terms of the internal structure of his films.

Gatlif's fiction films gain a documentary-like appearance with elements such as the close connection of the subjects with real life, the fact that he plays real people in his films, and his use of real places. Unlike in mainstream cinema, randomness is more prominent than a sequential plot in these films. It is not possible to guess what will happen next scenes as in real life. In this sense, in these kinds of films, there is a pursuit of kind of a reality or a meaning. From this point, he designs the fictional world in an approach resembling the relationship that French New Wave directors established between daily life and film space.

Another aspect of Gatlif's search for reality is the use of cameras. In these films, just like the characters, the camera is also in search of. The camera is often mobile; walks around characters, focuses on the faces, instruments, hands, feet. At this point, there is a style similar to the Dogma movement in terms of establishing the camera language on the search for reality.

From this aspect, as in Siegfried Kracauer's "redemption of physical reality" description (1997), he tries to find hidden meanings in details that the viewer cannot with a naked eye by using close-ups, and by overflowing beyond the dominant view's perception and transforming the look; thus he tries to generate meanings. It creates an alienating effect by suddenly moving from general plans to faces, making jumping transitions, and forces the viewer to think about what they see. For example, at the beginning of the movie Transylvania, the camera passes through the villages and rural areas with very fast scrolls, the close-up and still images of the people living there suddenly cut this rapid flow and the meanings reflected on human faces among the rapid transitions of spaces create a flash effect.

In these films, the staging does not take place by using general plans, shot-reverse-shot, over the shoulder shots in order. The randomness that drives the events also determines the frames. In this pursuit, the camera often views the faces. Frequently, faces are imaged in closeup, with no headspace, foreheads cut and looking directly into the camera. Even in Indignados, the interaction of the children with the camera, and their interacting with the viewers through the camera is enabled. Gatlif seeks the meanings expressed in the body and faces. In these films, there is a preference for cinematography that makes sense of the existence made and displayed on faces, various parts of the body, not in the context of the environment, but in the context of itself. In this respect, close-ups on faces, cuts made from general plans to faces, and causing jumping transitions are elements of Gatlif's unique cinematography.
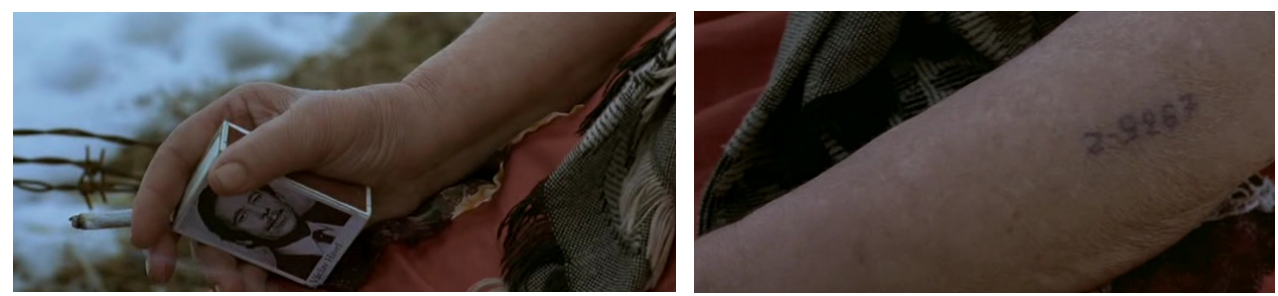

Image 8: The camera searches for meanings that we are unaware of via close-ups: Pictures from Latcho Drom... 
In connection with the use of music and dance as an important narrative element in most of the Gatlif films, the feet that dance, walk and run rhythmically are used as if they have a separate existence from the whole of the body, and often without showing who they belong to. This preference implies the theme of a journey, not being bound by the boundaries of a particular place or culture that characterizes the director's cinema. Feet are the machines that enable multiculturalism, cultural hybridity, passing over spatial and cultural borders, passing over stabilities and norms, affirming the difference, and opening the body they belong to a becoming.

The director's cinematic language apart from major cinema narrations and marking minor meanings reflects an original style in terms of building up spaces. The director often visualizes spaces as masterfully framed paintings. Inner journeys of characters that are seen in general plans inside buildings, alleys, electric and phone poles, roads, etc. take place in spaces that are constantly changing and resembling perfect pictures.

The framing of spaces that do not fit into a certain context, often with unfamiliar angles, close or general plans, reveals a rhizomatic and immanent expression in terms of cinematography. The rhizomatic signification of spaces also plays an important role in the establishment of the carnivalesque space that forms the basis for the search of the characters.
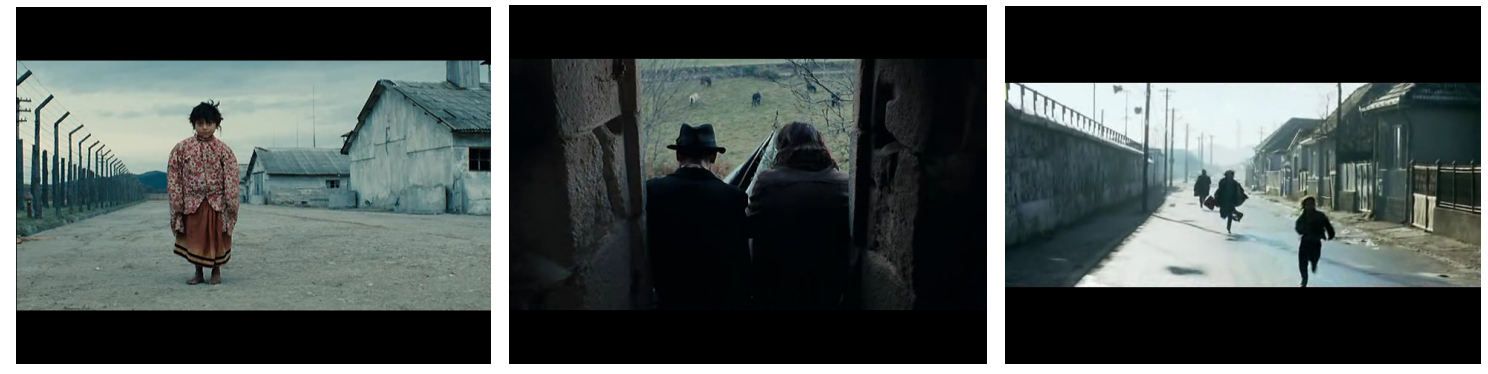

Image 9: In Gatlif's cinematography, photographic images of spaces contain rhizomatic meanings: Scenes from Korkoro and Transylvania.

Gatlif also presents a unique approach in terms of sound usage. For example, elements such as the overlapping voices in the documentary Indignatos, the successive utterance of the same words by both the narrator and different people in the film, and the asynchronous use of the voices of the characters who look at the camera and remain silent exemplify an original approach in the documentary style.

The search for meaning in sounds, extraordinary photographic images of places, faces, parts of the body such as hands and fingers, or close-ups of various objects reminds us of the construction of difference and meaning in an immanent plane in the Deleuzian sense. Through the elements that the self inner meaning is pursued by becoming abstracted from the universe of meaning it belongs to through close and extraordinary shots, the meaning is examined along the difference axis; and a minor cinema style is put forward which centers on plurality, nomadism, and ambivalence through meanings whose belonging bonds are broken off through deterritorialization.

\section{Conclusion}

Tony Gatlif, a multi-cultured, multi-identified director, tells the stories of the nomads, gypsies, subordinates, angry people in most of his films, and presents his accented voice which found his origins in his own nomadism through these narrations. Gatlif's characters are free spirits, just like himself, independent of their ethnic identity, whose belonging depends on roads and journeys and therefore do not fit into any of the existing categorizations. Through these characters, the director describes the cultural encounters, intercultural interactions, and 
relationality of being on the road, while also establishing nomadism on the axis of moving away from the dominant narratives, fixations, and ties of belonging.

Although the relationship between the nomad and the majorative is sometimes seen in othering, exclusion, and conflict in Gatlif films, the director problematizes the nomadic characters mostly within their own immanent worlds. He handles gypsy or nomadism as a conscious choice and defines the way of expression of nomadism, the enrichment offered by spatial and cultural displacement and hybridization, within a positive perspective of difference in the Deleuzian sense, within the framework of the continuity and affirmation of difference. The director processes nomadism not so much as a traumatic journey between a start and a finish point, but as a way of pursuing form in which the characters transform their own worlds and opening their subjectivities to new possibilities with the differences, they added to themselves.

Tony Gatlif's accented cinema which is characterized in themes such as searches of identity, the journeys for the discovery of original bonds, displacement, forced migration, being intercultural, hybridity, etc. can be evaluated in terms of the director's approach on journey progress and the points reached in these journeys as a minor cinema which deterritorializes the major one, and opens a field to the alternative and becoming.

These narrations take individual stories to the center, take the characters to new and indefinite starts and molecular subjectivities by purging from all bonds that signify themselves, and by moving them away from the molar signification universes which frame them and simply leaves them on the verge of uncertainty. He does not suggest a new way or presents new narrations. This new ontological state which abolishes borders makes meta narrations meaningless, signifies a multi-cultured and dialogical being, corresponds to "becoming" in Deleuzean meaning. Just like Deleuze and Guattari's approach to thought not as a pursuit of reality but as a process of the invention with rhizomatic or nomadic thinking that is situated against the major thinking structures; Gatlif forms a minorative style turning towards the pursuit of the single instead of the universal through the cinema he has built on nomadic becoming. He generates minor lives, trends, pursuits, and ideas through characters that pass beyond the boundaries of the major. He provides political openings by starting from the individual or by telling the story of a group.

Gatlif realizes these minor quests within a unique cinematographic construction, by breaking some of the dominant codes of cinema. Many elements that build the language of cinema, such as story, language, music, words, places, frames, camera movements, editing are different from the majorative usages in cinematic expression. The carnivalesque approach, which makes intellectual inquiries possible, also dominates the language of cinema. In this way, while Gatlif presents an original approach to existence by presenting multiplicity, nomadism, and becoming in a philosophical sense, he also produces a minor cinema with the immanence of his cinema. Thus, he shows that cinema is a form of thinking; it is a field of producing thoughts, concepts, and meaning just like philosophy.

\section{Conflict of Interest Statement}

The author certifies that there is no conflict of interest.

\section{The Researchers' Statement of Contribution Ratio Summary:}

The authors certify that they contributed to the article with a percentage of $50 \%$ and $50 \%$ 


\section{References}

Akay, A. (2006). “Yersizyurtsuzlaşma Üzerine”, Toplumbilim, 5, pp. 19-22.

Akyol Oktan, K. (2019). “Tekillik, İnsan-Sonrası (Post-Human) ve Göçebe Cinsiyetler”.

E.Baştürk ve B. N. Erdem (Ed.), in, Dijital Medya ve Toplumsal Cinsiyet- Kavramlar Fırsatlar Sinırllıklar, Konya: Litera-Türk, pp. 283-318.

Altun, H. (2016). “Tony Gatlif’ in Sinematografik Evreninde Farklı Veçheleriyle Göçün Temsili", International Symposium On Migration and Culture, pp. 193-216.

Andrew, M. (2008). “French Cinema in Exile: Trans-national Cultural Representation in Tony Gatlif's Gadjo dilo", New Cinemas: Journal of Contemporary Film, 6/2, pp. 75-83.

Bakhtin, M. (2001). Karnavaldan Romana Edebiyat Teorisinden Dil Felsefesine Seçme Yazılar, Trans. byCem Soydemir, İstanbul: Ayrıntı Publishing.

Blum-Reid, S. (2008). "Away from Home? Two French Directors in Search of their Identity", Quarterly Review of Film and Video, 26:1, pp. 1-9.

Butler, J. ve Athanasiou, A. (2017). Mülksüzleşme \& Siyasaldaki Performatif, Trans. by Başak Ertür, İstanbul: Metis Printing.

Colebrook, C. (2013). Gilles Deleuze, Trans. by Cem Soydemir, Ankara: Doğu Batı Publishing. Çakan, G. (2009). “Tony Gatlif”, https://www.bagimsizsinema.com/tony-gatlif.html, Access Date: 15.10 .2021$.

Çalcı, S. (2012). “Deleuze ve Guattari' de Dilin Yersiz-yurtsuzlaşması: Emir Sözcüklerden Tercihler Mantığına", Journal Of Thinking, 2, pp. 6-27.

Deleuze, G. \& Guattari, F. (1994). What Is Philosophy? New York: Columbia University Press.

Deleuze, G. \& Guattari, F. (2005). A Thousand Plateaus: Capitalism and Schizophrenia, Trans. by Brian Massumi, Minneapolis: University of Minnesota Press.

Deleuze, G. \& Guattari, F. (2020). Kafka: Minör Bir Edebiyat İçin, Trans. by Işık Ergüden, İstanbul: Sel Publishing.

Deleuze, G. \&Parnet, C. (2007). Dialogues II, Trans. by Hugh Tomlinson \& Barbara Habberjam, New York: Columbia University Press.

Deleuze, G. (1994). Difference and Repetition, Trans. by Paul Patton, New York: Columbia University Press.

Deleuze, G. (1997). Cinema 2: The Time Image, Mineapolis: University of Minesota.

Deleuze, G. (2004). The Logic of Sense, Trans. by Mark Lester with Charles Stivale, London: Continuum.

Foucault, M. (1997). “Of Other Spaces: Utopias and Heterotopias”, Neil Leach (ed), in, Rethink ing Architecture: A Reader In Cultural Theory, London, New York : Routledge, pp. 350-356.

Gatlif, T. (1992). Latcho Drom [Movie], France: K. G. Productions.

Gatlif, T. (1997). Gadjo Dilo [Movie], Romania, France: CNC, Princess Films, Canal+. 
Gatlif, T. (2000). Wengo [Movie], France: Princes Films, Arte France Cinéma, Astrolabio Pro ducciones S.L., et al.

Gatlif, T. (2001). Swing [Movie], France: Princes Films, Centre national du cinéma et de l'image animée (CNC), Région Alsace, et al.

Gatlif, T. (2004). Exils [Movie], France: Princes Films.

Gatlif, T. (2006). Transylvania [Movie], France: Canal+, TPS Star.

Gatlif, T. (2009). Korkoro [Movie], France: Production Princes, France 3 Cinema, Rhone-Alp Cinema.

Gatlif, T. (2012). “On Sauve Les Banques, Pas Le People”, https:/ / www.huffingtonpost.fr/ tony-gatlif/on-sauve-les-banques-pas-_b_1379618.html,Access Date: 15.10.2020.

Gatlif, T. (2014). Geronimo [Movie], France: Princes Films, Région Rhône-Alpes, Canal+, et al. Gatlif, T. (2018). Djam [Movie], France, Greece, Turkey: Princes Production.

Kracauer, S. (1997). Theory of Film:The Redeption of Physical Reality, New Jersey: Princeton Uni versity Press.

Naficy, H. (2001). An Accented Cinema: Exilic And Diasporic Filmmaking, New Jersey: Princeton University Press.

Nietzsche, F. W. (2007). Beyond Good and Evil: Prelude to a Philosophy of the Future, Rolf-Peter Horstmann and Judith Norman (Ed.), Trans. by Judith Norman, Cambridge: Cambridge University.

Stavrides, S. (2016). Kentsel Heterotopya: Özgürleşme Mekânı Olarak Eşikler Kentine Doğru. Trans. by Ali Karatay, İstanbul: Sel Publishing.

Sutton, D. \& Jones, D. M. (2016). Yeni Bir Bakışla Deleuze,Trans. by Murat Özbank \& Yetkin Başkavak, İstanbul: Kolektif Kitap.

Vanderschelden, İ. (2014) . “Close-Up: Postcolonial Filmmaking in French-speaking Countries", Black Camera, 6/1, pp. 108-123. 